\title{
Major Causes of Liver Condemenation and its Economic Significance in Small Ruminanats Slaughtered at Luna Export Abattoir, East Shoa Zone, Centeral Ethiopia
}

\author{
Elias Gezahegn ${ }^{1 *}$, Birhanu Abera², Dinku Assefa ${ }^{3}$ and Hussen Yunus \\ ${ }^{1}$ Bale Zone Pastoral Area Development Office, Ethiopia \\ ${ }^{2}$ Asella Regional Veterinary Laboratory, Ethiopia \\ ${ }^{3}$ Yem Special District Livestock Development and Fishery Office, Ethiopia \\ ${ }^{4}$ Bale Zone Livestock Development and Fishery Office, Ethiopia
}

\begin{abstract}
A study was conducted from December, 2014 to April 2015 to identify the major causes of liver condemnation and its economic significance in small ruminants slaughtered at Luna Export Abattoir, Ethiopia. By considering age, origin and species as a risk factors major abnormalities encountered were identified and considered accordingly. A simple random sampling was used where 384 each sheep and goats were sampled with a total of 768 animals and postmortem examinations was applied on liver. Out of 768 sheep and goats slaughtered $67.7 \%$ of liver revealed total condemnation. The major cause of these liver condemnations are due to Cysticercus tenuicullosis (11.5\%), Calcification (20.31\%), Cloudiness (20.57\%), Cirrhosis (5.08\%), Hepatitis $(5.9 \%)$, Fatty degeneration $(2.99 \%)$, Steilesia hepatica $(3.65 \%)$, Adhesion $(7.42 \%)$, and Hydatidosis $(0.13 \%)$. Except in C. tenuicollis, calcification and cloudiness $(p<0.05)$ which has a significance difference were observed between sheep and goats, insignificance difference $(p>0.05)$ were recorded between sheep and goats in other lesions. Concerning the origin of the animal significance difference $(p<0.05)$ in cloudy lesion were observed on sheep originated from Somali, GammuGoffa and Awash but insignificant difference observed in another lesion. Similarly, significance difference were observed in $C$ tenuicollis, Calcification, and fatty degeneration $(p<0.05)$, among goats originated from Borena, Afar and Wollo and insignificance difference was observed in other lesions. Regarding age and species in other lesions different rates of prevalence were recorded in the current study. Moreover, from total condemnation rate of liver, economic loss of 335,000.00 USD per annum was estimated. Due to such small ruminant health problems and these pathological lesions results in significance economic loss in small ruminants, continuous surveillance and strategically prevention and control of these abnormalities shall be implemented in these animals.
\end{abstract}

Keywords: Liver; Condemnation; International market; Economic; Abattoir; Small ruminant

\section{Introduction}

The total number of Sheep and goats in Ethiopia is estimated to be nearly 48 million. Sheep and goats are widely adapted to different climates and are found in all production systems [1], They generate cash income from export of meat, edible organs, skins and live animals. There is also a high domestic meat demand from these animals, particularly during religious festivals [2], Hence, an increase in small ruminant's production could contribute to the attainment of food self-sufficiency in the country, particularly in response to the protein requirement for the growing human population as well as to enhance the export earnings [3].

Even though this sub-sector contributes much to the national economy, its development is hampered by various constraints. These include endemic animal diseases, poor nutrition, poor husbandry, poor infrastructure and shortage of trained labor and lack of government policies [4], Each year a significant loss result from, death of animals, inferior weight gain, condemnation of edible organs and carcass at slaughter. This production loss to the livestock industry is, estimated at more than 900 million USD annually [5].

The 2009/10 annual report of the veterinary services [6], indicated that out of 1,261,886 animals slaughtered at all export abattoirs during the year 2009/10; 379,517 liver, 336,536 lungs; 13,722 kidneys; and 5,809 heart were condemned. The organs which were found affected with disease and abnormalities were mostly liver and lung and they accounted for $49.1 \%$ and $43.5 \%$ respectively of the total rejections [6].
In view of this proper evaluation of economic loss due to major causes of liver condemnation in sheep and goats at abattoir surveillance is needed which of great relevance.

Therefore, the objective of this study was-

- To determine the major causes of liver condemnation in small ruminants slaughtered at Luna Export Abattoir.

- To estimate the magnitude of direct Economic loss incurred due to condemned liver.

\section{Materials and Methods}

\section{Study area}

The study was conducted from December 2014 to April 2015 in the private owned Luna export abattoir, Modjo town, central Ethiopia. It has a latitude and longitude of $8^{\circ} \mathrm{N} 39^{\circ} \mathrm{E}$ with an elevation between 1788

*Corresponding author: Elias Gezahegn, Bale Zone Pastoral Area Development Office, Ethiopia, Tel: +31887555555; E-mail: eluccaa@gmail.com

Received December 27, 2016; Accepted January 20, 2017; Published January 25, 2017

Citation: Gezahegn E, Abera B, Assefa D, Yunus H (2017) Major Causes of Liver Condemenation and its Economic Significance in Small Ruminanats Slaughtered at Luna Export Abattoir, East Shoa Zone, Centeral Ethiopia. J Vet Sci Technol 8 : 422. doi: 10.4172/2157-7579.1000422

Copyright: (c) 2017 Gezahegn E, et al. This is an open-access article distributed under the terms of the Creative Commons Attribution License, which permits unrestricted use, distribution, and reproduction in any medium, provided the original author and source are credited. 
Citation: Gezahegn E, Abera B, Assefa D, Yunus H (2017) Major Causes of Liver Condemenation and its Economic Significance in Small Ruminanats Slaughtered at Luna Export Abattoir, East Shoa Zone, Centeral Ethiopia. J Vet Sci Technol 8: 422. doi: 10.4172/2157-7579.1000422

Page 2 of 5

and $1825 \mathrm{~m}$. a. s. 1. [7], The Luna export slaughter house was established in 2003 and located in Modjo town with 50,000 square meters of area. This is one of the abattoirs which export meat to Saudi Arabia, Turkey, Egypt and United Arab Emirates

\section{Study populations}

Study populations are apparently healthy of sheep and goats, slaughtered at Luna Export Abattoir, Modjo town. The origins of slaughtered animals are from different areas of the country such as, Borena, Afar, Somali, Wollo, Eastern Hararghe and the Southern part of the country. The study conducted in the Luna Export abattoir indicates that most of the animals are comes from pastoral and semipastoral areas, which are preferred breeds.

\section{Study design and sampling method}

The cross-sectional abattoir survey was conducted on slaughtered sheep and goats to determine the major causes of liver condemnation. A simple random sampling method is employed and the study animals were randomly selected and recorded tagged and followed up throughout the whole slaughtering process. The required sample size of the study for both species of animals was determined by the formula given in [8], $50 \%$ expected prevalence with $95 \%$ of Confidence interval and at $5 \%$ desired precision.

Thrus field formula $=n=\frac{1.96^{2}\left(P_{\text {exp }}\left(1-P_{\text {exp }}\right)\right.}{d^{2}}$

Where $\mathrm{n}=$ Required sample size

Pexp=Expected prevalence

$\mathrm{d}^{2}=$ Desired absolute precision

Hence, the required sample sizes for each species were $=384$ and 768 samples were used for both species.

\section{Abattoir survey}

Postmortem inspection: Post-mortem examination involved visual inspection, palpation and making systemic incision of liver to look for the presences of cysts, adult parasites, and other abnormalities. Pathological lesions were differentiated and judged based on FAO guidelines on meat inspection for developing countries [9].

Economic loss assessment: The direct Economic losses incurred due to liver condemnation were, estimated by using the formula indicated below [10].

\section{$\mathrm{EL}=\left[\mathrm{S}_{\mathrm{SR}} \mathrm{X} \mathrm{OC}_{\mathrm{Li}} \mathrm{X} \mathrm{R}_{\mathrm{Li}}\right]$}

Where $\mathbf{E L}=$ Estimated annual economic loss due to liver Condemnation.

$\mathrm{S}_{\mathrm{SR}}=$ Annual shoats slaughter rate of the abattoir

$\mathbf{O C}_{\mathrm{LI}}=$ Average cost of liver / cost of rejected liver
$\mathbf{R}_{\mathrm{Li}}=$ Rejection rate of liver.

So, to calculate the above formula the following data is considered.

- The annual slaughter rate of the abattoir

- The average retail market of the liver.

- The rejection rate of the liver will be required.

Data management and analysis: Data generated from postmortem inspection was recorded in the Microsoft Excel 2007 program. Descriptive statistics was used to determine the variation between condemnation rates of the liver in relation to, the origin of the animal and age groups were evaluated by person's chi-square $\left(\mathrm{X}^{2}\right)$ and percentage. The significance among and/or between rejection rates of specific organs in age groups, origins and species of animals were evaluated using $p$-value where it is significance if $(\mathrm{p} \geq 0.05)$.

\section{Results}

\section{Postmortem examination}

As shown in Tables 1 and 2, from all examined animals, the major causes for liver condemnations are cloudiness (20.57\%), calcification, (20.31\%), C. tenuicollis, (11.46\%) and adhesion (7.42\%) are the major causes for rejection of the liver from international market and also miscellaneous factors are a principal causes for liver condemnations. Generally, these causes of the liver found to be high in goats than in sheep with a high significance ( $\mathrm{p} \geq 0.05)$ in first three abnormalities.

Among the origin of animals, although insignificance difference was observed in all abnormalities but cloudiness has a significance $(\mathrm{p}<0.05)$ in sheep, and C. tenuicollis, calcification and fatty degeneration has $(\mathrm{p}<0.05)$ in goats (Table 3$)$.

With regard to age group except cirrhosis in sheep P-value $(\mathrm{p}<0.05)$, and $C$. tenuicollis, and miscellaneous abnormalities in goat $\mathrm{P}$-value $(\mathrm{p}<0.05)$, but all other liver abnormalities observed in current study shows insignificance difference between considered age groups (Table 4).

\section{Economic loss assessment}

The annual direct economic loss incurred due to condemned liver as a result of pathological, parasitological and other abnormalities at abattoir were estimated from international market of the abattoir estimated to be $3,685,000$ ETB (Ethiopian Birr) or 184,250 USD (United States Dollar) in present study. The cost analysis guidance was as shown in Table 5 below. The liver of sheep and goats are similar and weighs 500-700 gram [11].

\section{Discussion}

In this study from 768 samples taken from both sheep and goats $520(67.7 \%)$ samples were found positive for one or more lesion

\begin{tabular}{|c|c|c|c|c|}
\hline \multirow{5}{*}{ Origin } & \multicolumn{4}{|c|}{ Number of animals examined } \\
\hline & Sheep & No & Goat & No \\
\hline & Somali & 218 & Borena & 202 \\
\hline & GamuGofa & 87 & Afar & 164 \\
\hline & Awash & 79 & Wollo & 18 \\
\hline Total & & 384 & Total & 384 \\
\hline \multirow{2}{*}{ Age } & Young & 101 & Young & 214 \\
\hline & Adult & 283 & Adult & 170 \\
\hline Total & & 384 & Total & 384 \\
\hline
\end{tabular}

Table 1: Random sample distributions in relative to Species, origin and age. 
Citation: Gezahegn E, Abera B, Assefa D, Yunus H (2017) Major Causes of Liver Condemenation and its Economic Significance in Small Ruminanats Slaughtered at Luna Export Abattoir, East Shoa Zone, Centeral Ethiopia. J Vet Sci Technol 8: 422. doi: 10.4172/2157-7579.1000422

Page 3 of 5

which is $245(31.9 \%)$ and $275(35.8 \%)$ positive samples from sheep and goats respectively rejected. Major causes of liver condemnations from international market were found to be Cloudiness $(20.57 \%)$, Calcification (14.58\%), C. tenuicollis (16.67\%), Adhesion (7.42\%), Cirrhosis (5.47\%) and Hepatitis (5.99\%) found to be the major causes of liver condemnations in the abattoir. From both species of animals goats were mostly affected and responsible for high rejection rate of the liver, which has a statistical significance value $(\mathrm{p}<0.005)$. This is due to the feeding habit of the animals in which sheep are grazers, whereas goats feed substantial amount of browse and mostly exposed to toxic plants especially of from low land areas, which resists the dry periods [12], results damage to the liver.

From the sheep samples, drawn from different origins cloudiness is more in sheep brought from Somali origin, and has a significance value $(\mathrm{P}<0.05)$. It is probably due to the fact that vegetative coverage of the arid and semi arid weather conditions, plants that are found there can resist drought and are mostly toxic plants and ingestion of these plant leaves resulting cloudy degeneration of the liver, responsible for rejection because of aesthetic value and hazard to public Gracey et al. [13], suggests the same reason.

In this study, hydatidosis has low prevalence only $(0.26 \%)$ and $(0.00 \%)$ in sheep and goats respectively as the same as Getachew and Mesfin and Mekonnen [14], also reported that $0 \%$ of hydatidosis of goats in Hawassa and Luna export abattoir respectively. This is probably due to that low population of dogs, which is the definitive host in the pastoral and semi-pastoral areas, which decrease the contact between dogs with sheep and goats. On the other hand, the difference between the prevalence of sheep (1) and goat (0) hydatidosis is due to feeding habit of goats that are mostly browsers Kusiluka and Kambarage, Abdella [15], reported that from 1476 samples of sheep and goats from three abattoirs (Hashim, Elfora and Luna) reported that all recovered cysts except three ( 2 sheep and 1 goat located in the liver) were located in lungs in both sheep and goats. In addition, [16], reported that hydatid cysts were more frequently observed in the lungs than livers of small ruminants.

\begin{tabular}{|c|c|c|c|c|c|}
\hline \multirow{2}{*}{ Major Causes } & \multirow{2}{*}{$\begin{array}{c}\text { Out of } 768 \\
\text { Total Prevalence } \\
\text { No. }(\%)\end{array}$} & \multicolumn{4}{|c|}{ Species Prevalence } \\
\hline & & Sheep (384) No. (\%) & Goat (384) No. (\%) & $x^{2}$ & P-value \\
\hline C. tenuicollis & $88(11.46)$ & $24(6.25)$ & $64(16.67)$ & 20.5348 & 0.000 \\
\hline Calcification & $156(20.31)$ & $100(26.04)$ & $56(14.58)$ & 15.5737 & 0.000 \\
\hline Cloudiness & $158(20.57)$ & $67(17.45)$ & $91(23.70)$ & 4.5898 & 0.032 \\
\hline Cirrhosis & $39(5.08)$ & $18(4.69)$ & $21(5.47)$ & 0.2431 & 0.622 \\
\hline Hepatitis & $45(5.86)$ & $22(5.73)$ & $23(5.99)$ & 0.0236 & 0.878 \\
\hline Fatty. Degeneration & $23(2.99)$ & $9(2.34)$ & $14(3.65)$ & 1.1205 & 0.290 \\
\hline S. hepatica & $28(3.65)$ & $11(2.86)$ & $17(4.43)$ & 1.3344 & 0.248 \\
\hline Adhesion & $57(7.42)$ & $24(6.25)$ & $33(8.59)$ & 1.5350 & 0.215 \\
\hline Hydatid cyst & $1(0.13)$ & $1(0.26)$ & $0(0.00)$ & 1.0013 & 0.317 \\
\hline Others & $35(4.56)$ & $13(3.39)$ & $22(5.73)$ & 2.4248 & 0.119 \\
\hline Total & $630(82.03)$ & $289(75.26)$ & $341(88.8)$ & & \\
\hline
\end{tabular}

Table 2: Distributions of major causes of liver condemnations in small ruminants.

\begin{tabular}{|c|c|c|c|c|c|c|c|c|c|c|c|c|}
\hline Species & $\begin{array}{c}\text { No. } \\
\text { examined }\end{array}$ & Origin & 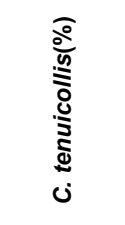 & 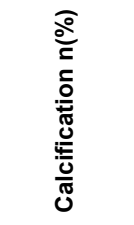 & 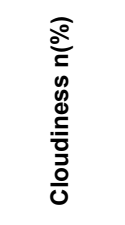 & 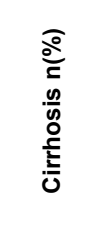 & 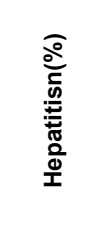 & 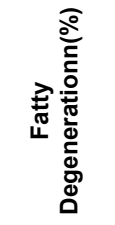 & 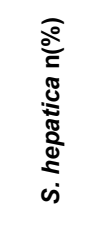 & 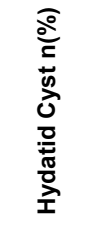 & 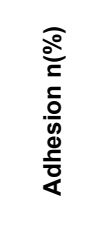 & 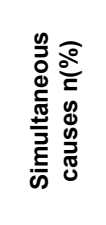 \\
\hline Sheep & $\begin{array}{c}210 \\
89 \\
79\end{array}$ & $\begin{array}{c}\text { Somali } \\
\text { GG } \\
\text { Awash }\end{array}$ & $\begin{array}{c}15(6.88) \\
5(5.75) \\
4(5.06)\end{array}$ & $\begin{array}{c}63(28.90) \\
20(22.9) \\
17(21.52)\end{array}$ & $\begin{array}{c}37(16.9) \\
7(8.05) \\
23(29.11)\end{array}$ & $\begin{array}{c}11(5.05) \\
3(3.45) \\
4(5.06)\end{array}$ & $\begin{array}{c}12(5.50) \\
6(6.90) \\
4(5.06)\end{array}$ & $\begin{array}{l}8(3.67) \\
4(4.60) \\
2(2.53)\end{array}$ & $\begin{array}{l}3(1.38) \\
2(2.30) \\
6(7.59)\end{array}$ & $\begin{array}{l}1(0.46) \\
0(0.00) \\
0(0.00)\end{array}$ & $\begin{array}{c}16(7.34) \\
8(9.20) \\
0(0.00)\end{array}$ & $\begin{array}{l}3(1.38) \\
5(5.75) \\
5(6.33)\end{array}$ \\
\hline \multirow[t]{2}{*}{ Total } & 384 & & $24(6.25)$ & $100(26.04)$ & $67(17.45)$ & $18(4.69)$ & $22(5.73)$ & $14(3.65)$ & $11(2.86)$ & $1(0.26)$ & $24(6.25)$ & 13(3.39) \\
\hline & & $\begin{array}{c}X^{2} \\
\text { P-value }\end{array}$ & $\begin{array}{l}0.37 \\
0.83\end{array}$ & $\begin{array}{l}2.18 \\
0.34\end{array}$ & $\begin{array}{l}12.83 \\
0.002\end{array}$ & $\begin{array}{l}0.39 \\
0.82\end{array}$ & $\begin{array}{l}0.30 \\
0.86\end{array}$ & $\begin{array}{l}0.50 \\
0.78\end{array}$ & $\begin{array}{c}8.19 \\
0.017\end{array}$ & $\begin{array}{c}0.7635 \\
0.683\end{array}$ & $\begin{array}{c}6.99 \\
0.030\end{array}$ & $\begin{array}{c}6.27 \\
0.044\end{array}$ \\
\hline Goat & $\begin{array}{c}202 \\
264 \\
18\end{array}$ & $\begin{array}{c}\text { Borena } \\
\text { Afar } \\
\text { Wollo }\end{array}$ & $\begin{array}{c}24(11.88) \\
35(21.34) \\
5(27.78)\end{array}$ & $\begin{array}{c}16(7.92) \\
29(17.68) \\
11(61.11)\end{array}$ & $\begin{array}{c}46(22.77) \\
40(24.39) \\
5(27.78)\end{array}$ & $\begin{array}{c}11(5.45) \\
8(4.88) \\
2(11.11)\end{array}$ & $\begin{array}{l}10(4.95) \\
11(6.71) \\
2(11.11)\end{array}$ & $\begin{array}{c}3(1.49) \\
4(2.44) \\
2(11.11)\end{array}$ & $\begin{array}{c}12(5.94) \\
4(2.44) \\
2(11.11)\end{array}$ & $\begin{array}{l}0(0.00) \\
0(0.00) \\
0(0.00)\end{array}$ & $\begin{array}{l}12(5.94) \\
18(10.9) \\
3(16.67)\end{array}$ & $\begin{array}{c}11(5.45) \\
9(5.49) \\
2(11.11)\end{array}$ \\
\hline \multirow[t]{2}{*}{ Total } & 384 & & $64(30.5$ & $56(28.90$ & $91(24.98$ & $21(7.15)$ & 23(5.01 & $9(5.01$ & $18(6.5)$ & $0(0.00)$ & $33(11.2)$ & $22(7.35)$ \\
\hline & & $\begin{array}{c}X^{2} \\
\text { P-value }\end{array}$ & $\begin{array}{c}7.5112 \\
0.023\end{array}$ & $\begin{array}{c}39.7445 \\
0.000\end{array}$ & $\begin{array}{c}0.3049 \\
0.85\end{array}$ & $\begin{array}{c}1.2194 \\
0.544\end{array}$ & $\begin{array}{c}1.3759 \\
0.503\end{array}$ & $\begin{array}{c}6.7022 \\
0.035\end{array}$ & $\begin{array}{c}5.6101 \\
0.061\end{array}$ & - & $\begin{array}{c}4.4880 \\
0.106\end{array}$ & $\begin{array}{c}1.0131 \\
0.603\end{array}$ \\
\hline
\end{tabular}

Table 3: Summary of the rejection rate of liver condemnations based on Origin of the sheep and goats. 


\begin{tabular}{|c|c|c|c|c|c|c|c|c|c|c|c|c|}
\hline Species & $\begin{array}{c}\text { No. } \\
\text { examined }\end{array}$ & Age & 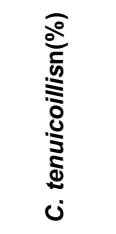 & 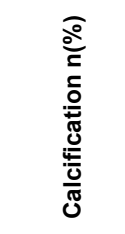 & $\begin{array}{l}\frac{\partial}{0} \\
= \\
0 \\
0 \\
\frac{0}{0} \\
\frac{0}{0}\end{array}$ & 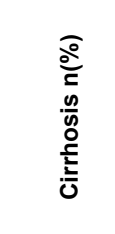 & 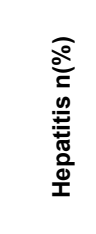 & 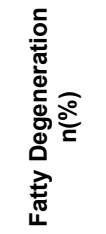 & 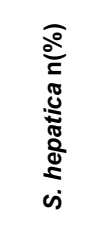 & $\begin{array}{l}\frac{\partial}{\varrho} \\
\frac{c}{c} \\
\frac{0}{y} \\
\frac{c}{0} \\
\frac{0}{4}\end{array}$ & 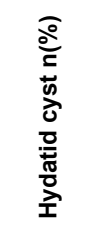 & 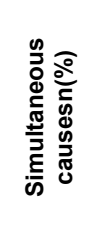 \\
\hline Sheep & $\begin{array}{l}101 \\
283\end{array}$ & $\begin{array}{l}\text { Young } \\
\text { Adult }\end{array}$ & $\begin{array}{c}6(5.94) \\
18(6.36)\end{array}$ & $\begin{array}{c}25(24.7) \\
75(26.5)\end{array}$ & $\begin{array}{l}24(23.7) \\
43(15.1)\end{array}$ & $\begin{array}{c}10(9.90) \\
8(2.83)\end{array}$ & $\begin{array}{c}7(6.9) \\
15(5.3)\end{array}$ & $\begin{array}{c}2(1.98) \\
12(4.24)\end{array}$ & $\begin{array}{l}5(4.95) \\
6(2.12)\end{array}$ & $\begin{array}{c}6(5.94) \\
18(6.36)\end{array}$ & $\begin{array}{l}0(0.00) \\
1(0.35)\end{array}$ & $\begin{array}{l}6(5.94) \\
7(2.47)\end{array}$ \\
\hline \multirow[t]{2}{*}{ Total } & 384 & & $24(6.25)$ & $100(26.0)$ & $67(17.4)$ & 18(4.69) & $22(5.7)$ & $14(3.65)$ & $11(2.86)$ & $24(6.25)$ & $1(0.26)$ & $13(3.3)$ \\
\hline & & $\begin{array}{c}X^{2} \\
\text { P-value }\end{array}$ & $\begin{array}{c}0.0224 \\
0.881\end{array}$ & $\begin{array}{c}0.1183 \\
0.731\end{array}$ & $\begin{array}{c}3.7937 \\
0.051\end{array}$ & $\begin{array}{c}8.3374 \\
0.004\end{array}$ & $\begin{array}{c}0.3663 \\
0.545\end{array}$ & $\begin{array}{l}1.0823 \\
0.298\end{array}$ & $\begin{array}{c}2.1430 \\
0.143\end{array}$ & $\begin{array}{c}0.3578 \\
0.550\end{array}$ & $\begin{array}{c}0.0224 \\
0.881\end{array}$ & $\begin{array}{c}2.7356 \\
0.098\end{array}$ \\
\hline Goat & $\begin{array}{l}214 \\
170\end{array}$ & $\begin{array}{l}\text { Young } \\
\text { Adult }\end{array}$ & $\begin{array}{l}25(11.6) \\
39(22.9)\end{array}$ & $\begin{array}{l}28(13.0) \\
28(16.4)\end{array}$ & $\begin{array}{l}54(25.2) \\
37(21.7)\end{array}$ & $\begin{array}{c}9(4.21) \\
12(7.06)\end{array}$ & $\begin{array}{c}16(7.4) \\
7(4.1)\end{array}$ & $\begin{array}{l}3(1.40) \\
6(3.53)\end{array}$ & $\begin{array}{l}8(3.74) \\
9(5.29)\end{array}$ & $\begin{array}{c}16(7.48) \\
17(10.00)\end{array}$ & $\begin{array}{l}0(0.00) \\
0(0.00)\end{array}$ & $\begin{array}{l}7(3.27) \\
15(8.8)\end{array}$ \\
\hline \multirow[t]{2}{*}{ Total } & 384 & & $64(16.6)$ & $56(14.5)$ & $91(23.70)$ & $21(5.47)$ & $23(5.9)$ & $9(2.34)$ & $17(4.43)$ & $33(8.59)$ & $0(0.00)$ & $22(5.7)$ \\
\hline & & $\begin{array}{c}X^{2} \\
P \text {-value }\end{array}$ & $\begin{array}{c}8.6469 \\
0.003\end{array}$ & $\begin{array}{c}0.8722 \\
0.350\end{array}$ & $\begin{array}{c}0.6305 \\
0.427\end{array}$ & $\begin{array}{l}1.4919 \\
0.222\end{array}$ & $\begin{array}{c}1.8983 \\
0.168\end{array}$ & $\begin{array}{c}1.8736 \\
0.171\end{array}$ & $\begin{array}{c}0.5420 \\
0.462\end{array}$ & $\begin{array}{c}0.7679 \\
0.381\end{array}$ & - & $\begin{array}{c}5.4080 \\
0.020\end{array}$ \\
\hline
\end{tabular}

Table 4: Summary of rejection rate of liver condemnations in Sheep and Goats based on age.

\begin{tabular}{|l|c|c|c|}
\hline Species & $\begin{array}{c}\text { Annual slaughtering rate of } \\
\text { shoats }\end{array}$ & $\begin{array}{c}\text { Frequency of } \\
\text { Positives } \\
\text { No (\%) }\end{array}$ & $\begin{array}{c}\text { Average cost of liver from } \\
\text { market }\end{array}$ \\
\hline Sheep & 250,000 & 245 & 63.8 \\
\hline Goats & & 275 & 71.6 \\
\hline Total & 520 & 2 USD/Kg \\
\hline
\end{tabular}

Table 5: Liver rejection rate in small ruminant and related economic loss.

Though C. tenuicollis and S. hepatica do not have public health importance, they considered as an important cause of economic loss in the meat industry since liver harboring them, are rejected for aesthetic reasons. Similarly, Jibat [17-20], reported that out of 2688 animals examined one-tenth of the total condemned livers were due to mechanical damage that was caused by faulty practices during evisceration. However, in this study liver condemnations due to mechanical damage are low in Luna Export Abattoir, which is due to experienced personnel and good slaughtering operations.

Losses from liver condemnation were assumed to occur since hepatic pathology is associated to infection that might have public health and aesthetic value [16]. The current study disclosed that from 768 samples taken from both sheep's and goats 520 liver samples of sheep and goats liver rejected from international market, with an estimated annual economic loss of $3,685,000.00$ ETB or $335,000.00$ USD per annum.

\section{Conclusion and Recommendations}

Several diseases are the major concern to small ruminant farming as it causes extensive financial waste because of direct and indirect economic losses. In general pathological conditions and parasitic diseases were the major causes of financial loss through liver condemnations at Luna Export Abattoir, which may also reflect the same scenario in other slaughter houses in Ethiopia. To mitigate the economic and public health impacts of diseases of small ruminants, proper disposal of offal, prohibition of backyard slaughter of small ruminants, construction of slaughterhouses, better disease control strategies, enhancing animal welfare, adequate training of abattoir personnel on the slaughtering operation and regular deworming of dogs are recommended. Furthermore, Small ruminants ranching at pastoral areas where the shoat population is vast should be put into practice for the purpose of export market and the total (true) economic impact of the diseases of small ruminants at depth should be investigated. Since most cases of liver condemnation was found to be Cloudiness and Calcification caused by ingestion of toxic plants which are found in arid and semi arid areas further investigation is required to isolate them for many purposes. From public health and live stock disease control point of view, abattoir surveillance of these abnormalities were found to be important to take control measures.

\section{Acknowledgements}

The authors would like to thank the Luna Export abattoir for their unreserved cooperation and facilities that they provided for this study.

\section{Conflict of Interest}

The authors declare that they have no conflict of interest.

\section{References}

1. Adane H, Girma A (2008) Economic significance of Sheep and Goats. Sheep and Goats Production Handbook for Ethiopia. Alemu Y, Merkel RC (eds.) Ethiopia Sheep and Goat Productivity Improvement Program, pp: 2-3.

2. FAO (2010) Food and Agricultural Organization of the United Nation statistica year book.

3. Teferi M (2000) An epidemiological study on given pasteurellosis in Arsi, south east Ethiopia.

4. Jobre Y, Lobago F, Tiruneh R, Abebe G, Dorchies PH (1996) Hydatidosis in three selected regions in Ethiopia. An assessment trial on its prevalence on economic and public health importance. Rev Med Vet. pp: 797-804. 
Citation: Gezahegn E, Abera B, Assefa D, Yunus H (2017) Major Causes of Liver Condemenation and its Economic Significance in Small Ruminanats Slaughtered at Luna Export Abattoir, East Shoa Zone, Centeral Ethiopia. J Vet Sci Technol 8: 422. doi: 10.4172/2157-7579.1000422

Page 5 of 5

5. MOA (2009/10) Ministry of Agriculture: Animal and Plant Health Regulatory Directorate, Ethiopia. Animal Health Year Book, Inspection and Quarantine Services. p: 28.

6. EMPDA (1984) Educational Material and Distribution Agency. Atlas for secondary High school of Ethiopia. Kindergarten and Formula Curriculum division. Social Science Panel. Ministry of Education, Macmillan Publisher.

7. Thrusfield M (2005) Surveys. In: veterinary epidemiology, 3rd edn. Blackwell Science Ltd, London, pp: 228-246.

8. AO (1994) Manual on Meat Inspection for Developing Countries. Food and Agriculture Organization (FAO), Rome, Italy.

9. Ogurinade A, Ogurinade BI (1980) Economic importance of Fasciolosis in Nigeria. Trop Anim Health Prod. pp: 155-159.

10. Wilson WG (2005) Wilson's Practical Meat Inspection. 7th edn, Revised from the original text Practical Meat Inspection by Andrew Wilson. Blackwell Publishing, p: 52.

11. Zewde S, Lidetu D (2006) Sheep and Goat Flock Health.A Hand Book of Sheep and Goats Productivity Improvement Program (ESGIP). p: 213.

12. Gracey JF, Collins OS, Huey RJ (1999) Meat Hygiene. 10th edn. London. Bailliere Tindall, pp: 223-260.
13. Mesfin G, Mekonnen A (2014) Causes of Liver and Lung Condemnation among Apparently Healthy Slaughtered Sheep and Goats at Luna Abattoir, Modjo, Ethiopia. Middle-East J Scient Res 21: 2346-2351.

14. Kusiluka L, Kambarage D (1996) A hand book of Diseases of small ruminants in Sub-saharan Africa. Diseases caused by Helminthes. Overseas Development administration. Animal Health Program, pp: 8-9.

15. Budke CM, Deplazes P, Torgerson PR (2006) Global Socio Economic impact of cystic echinocccosis. Emerg Infec Dis. 12: 296-302.

16. Jibat TB (2006) Causes of organ and carcass condemnation in small ruminants slaughtered at HELMEX Abattoir, Debrezeit. Faculty of Veterinary Medicine Addis Ababa University, DVM Thesis, pp: 1-2.

17. ILCA (1993) International livestock center for Africa. A Hand book of African livestock statistics. Addis Ababa, Ethiopia.

18. LMA (2001) Livestock Marketing in Ethiopia: A review of structure, performance and development initiatives. Socio-economics and Policy Research Working, p: 52.

19. Radostits OM, Blood DC, Gay CC, Hinchllif FW (2007) Disease of the liver and pancreas: Veterinary Medicine. 9 edn. ELBS, Baiviere Tindall, London, UK, pp: 313-332.

20. Debrezeit, Addis Ababa University, DVM Thesis, p: 32. 